\title{
Guest Editor's Introduction
}

The purpose of this special issue of Social Science History is to bring together in one coherent whole recent findings on the nature of the American corporate network from its beginnings to the present day. Based on objective data accumulated from a variety of archival sources, and relying on rigorous statistical methodologies, the unexpected picture of continuity and cohesion presented in this issue raises problems for many widely held beliefs about the origin and function of interlocking directorships among corporations.

Ever since the famous Pujo investigations of 1912-1913 (Carosso, 1970), periodically, studies have been conducted by governmental entities and academic researchers which claim to present evidence for the existence of systematic patterns of corporate communication and influence that are created by those corporate directors who sit on two or more corporate boards. But the meaning of these seemingly regular patterns was so hard to pin down in any conclusive way that most social scientists and historians concluded that there was not very much to the whole business after all. In the last ten years, however, a new generation of social science investigators has approached the problem once again, building larger and more refined data bases and developing more powerful analytical methods that can take advantage of modern computer capabilities. The six articles in this special issue represent one major fruition of this sustained research effort.

All six share a common starting point. They begin with a matrix that consists of individual directors and the corporations of which they are directors. In technical terms, this is what sociologist Ronald Breiger (1974) calls a membership network, or a people-by-institutions matrix. As Breiger shows, such a matrix is the basis for any analysis of the structural relationships between organizations and institutions. Moreover, it contains the two kinds of human relationships of theoretical interest to social scientists-personal relationships and memberships in social col- 
lectivities. It is therefore possible to derive from this single matrix both institutional relationships that are created by the presence of common members and personal-level cliques, or acquaintance patterns, that are defined by common organizational affiliations. In the analyses to be presented in this special issue, the primary focus is on the structural patterns at the institutional level that are created by those corporate directors who sit on two or more corporate boards in the given corporate sample. There are only occasional references to the personal cliques that can be discerned by studying the matrix in such a way that institutions become the linkages among individuals.

Conceptually speaking, the two different types of analysis suggest two concepts that can be useful in thinking about corporations and their directors. At the institutional level, the analysis leads to the idea of a "corporate community," which can be defined in network terms as all those corporations that are linked into a network by common (interlocking) directors. The internal pattern or shape of the American corporate community, and how it has changed over time, is a major focus of this issue. At the personal level of analysis, thinking in terms of a people-byinstitutions matrix leads to the idea of "the inner group," which can be defined as all those directors who sit on two or more corporate boards within the corporate community. Empirical studies show that only $15 \%$ to $20 \%$ of all directors in the corporate community qualify for inner-group status by this definition. Although this clique level is seldom utilized in the articles that follow, the concept has been utilized to good advantage in studies that attempt to link the corporate community to the social upper class or to noncorporate institutions (Soref, 1976; Useem, 1978, 1979).

The studies that follow are coordinated to provide an overview of the American corporate network. They also have a common format, in that the introductions are generally brief and the results are presented before any theoretical implications or explanatory speculations are discussed. At the same time, there was little or no collaboration among the authors, and they were free to disagree with each other. Readers will thus find some 
differences of opinion from paper to paper even though the authors have many ideas in common. The articles are the beginning of a general discussion, not the conclusion.

They are arranged in a sequence that begins historically and then widens to include probes into various aspects of the modern corporate network. The issue begins with a paper by David Bunting that is based on interlocking directorates among the largest banks, insurance companies, and railroads for selected years in the nineteenth century and the first part of the twentieth century. Although the data for 1816 and 1836 are limited to banks, insurance companies, and railroads based in New York, they present a strong case that a corporate network has existed since the rise of modern corporate enterprises in the second decade of the nineteenth century. This surprising finding is at odds with the generally accepted wisdom that interlocks are a phenomenon of the late nineteenth century.

William Roy then traces the development of the national corporate network in the late nineteenth and early twentieth centuries. Using a sample of 12 industrial sectors that range from railroads to book publishing, his major finding is that a national network developed during this period around a core of railroad, coal, and telegraph companies, with banks slowly moving toward the center of the network as the twentieth century began.

Mark Mizruchi picks up where Roy leaves off, analyzing the development of the network from 1904 to 1974 . He shows that there is remarkable stability in the corporate community throughout this period despite certain minor changes on some measures, and he finds that banks are a central point in the network in all periods. The several different measures he applies to his data base allow him to explain why different theorists have reached varying conclusions about the evolution of the corporate community. He is able to argue that there has been an institutionalization of intercorporate relations, rather than a managerial revolution.

The article by Beth Mintz and Michael Schwartz deepens our understanding of the modern corporate network by examining the long-standing and controversial question of whether or not there are "interest groups" within the corporate community. 
Using new criteria for defining an interest group that seem to be more faithful to the concept as it was originally defined, they conclude that interest groups were a minor occurrence in the network of the 1960s.

My article with Harold Salzman expands our conception of the modern corporate network by studying the directors of several different types of nonprofit organizations that have been claimed to be close to or part of the corporate community. Using the same measures employed by Mizruchi, the major finding of this analysis is that many of these organizations are central elements in the corporate community when all directorship ties are included in the analysis, but that their centrality declines greatly when only the officers of these corporations and nonprofit organizations are considered.

The final article, by Donald Palmer, steps back from a concern with a specific time period or type of organization to tackle the more general question of the significance or meaning of corporate interlocks. It sheds light on this question by examining what happens when an interlock is accidentally broken by such events as death or retirement. Palmer's findings on several hundred broken ties in the 1960s allow him to test hypotheses from the interorganizational and intraclass theories of corporate interlocks. These two theories are explained fully in the first half of his paper, and they are discussed by Roy as well. Although none of the authors besides Palmer claims that his or her findings are an attempt to test the two competing theories in any strict sense of the word, those who do address the issue believe their results are highly compatible with a version of the class theory and difficult to explain from the competing perspective.

The net result of these six studies, then, is a panorama that has historical depth and systemic width. They leave no doubt that American corporate history includes a complex pattern of corporate interlocks that have existed since the beginning of the modern industrial economy, and there is at least the preliminary suggestion that the network includes far more than banks and corporations. These general findings are the heart of the special issue, more important than any interpretations of them, for they 
give historians and social scientists a new dimension to consider in contemplating many aspects of American economic and political history.

\author{
G. William Domhoff \\ University of California, Santa Cruz
}

\title{
REFERENCES
}

BREIGER, R. (1974) "The duality of persons and groups." Social Forces 53: 181-190.

CAROSSO, V. P. (1970) Investment Banking in America. Cambridge: Harvard University Press.

SOREF, M. (1976) "Social class and a division of labor within the corporate elite: a note on class, interlocking, and executive committee membership of directors of U.S. industrial firms." Sociological Quarterly 17: 360-368.

USEEM, M. (1978) "The inner group of the American capitalist class." Social Problems 25: 225-240.

- - (1979) "The social organization of the American business elite and participation of corporate directors in the governance of American institutions." American Sociological Review 44: 553-572.

G. William Domhoff is Professor of Psychology and Sociology at the University of California, Santa Cruz. He is the author of numerous books and articles on the distribution of power in the United States, including Who Rules America? (1967), The Higher Circles (1970), The Powers That Be (1979), and most recently Who Rules America Now? (1983). 